\title{
Tin Smelting
}

\section{The influence of tin \\ on ancient civilization cannot be overestimated.}

When alloyed with copper, tin forms bronze, a metal so important in the making of weapons and implements that an entire period of history (about 3000 to 1100 B.C., depending on location) is named "the Bronze Age."

Tin is a soft, silvery-white metal now widely used in plating steel cans for food containers; it is also found in solder and metals used for bearings. Tin is malleable and adaptable to rolling, extrusion, spinning, and other kinds of cold-working. Its melting point $\left(232^{\circ} \mathrm{C}\right)$ is low compared with common structural metals; its boiling point $\left(2603^{\circ} \mathrm{C}\right)$, however, is high. The interval between these two temperatures is greater than for most other metals, which means that loss by volatilization from a liquid melt or during alloying is insignificant.

Tin's chemical symbol, $\mathrm{Sn}$, is derived from the Latin term stannum, which originally denoted an alloy of lead and silver. However, an imitation of this silver-lead alloy could be made substituting about $67 \%$ tin. This imitation proved so popular that by the 4 th century A.D., stannum had come to mean tin.

Tin exists in two common allotropes, or forms-white tin (also called beta tin) and gray tin (or alpha tin), also called "tin pest." Gray tin is powdery and of little use, but through a kinetic crystalline transformation, gradually changes to white tin at temperatures above $13.2^{\circ} \mathrm{C}$. This transformation occurs particularly rapidly above $100^{\circ} \mathrm{C}$. The undesirable reverse transformation-white tin gradually degenerating into gray tin-can occur at temperatures below $13.2^{\circ} \mathrm{C}$, but is prevented by small additions of lead, copper, silver, gold, bismuth, or antimony.

Aristotle had described gray tin in the 4th century B.C. Coming to the 1st century A.D., Roman historian Pliny mentioned the use of a lead-tin alloy-solder-for joining metals. The Romans also produced eating utensils and other articles of copper coated with tin, which is nontoxic.
The first use of tin in making bronze (usually 5-10\% tin in copper) probably occurred in the Near East in the 4th millennium B.C., although accidental alloying of copper with tin impurities may have occurred before this. Early Egyptian copper implements contain as much as $2 \%$ tin, while early copper celts (axlike tools for dressing timbers) in Ireland contain up to $1 \%$ tin. Both of these alloys are probably accidental mixtures.

At the site of the city of Ur, bronze articles dating from about 3500 B.C. have been found. In Iran, bronze weapons, ornaments, tools, and chariot fittings dating from as early as 3000 B.C. have been found.

As a metal, bronze is harder and more easily cast in molds than pure copper. It was therefore preferred for the manufacture of tools, weapons, and ornaments. For thousands of years, tin bronze proved to be the best metal available for a wide variety of uses until it was superseded by iron. Bronze was not superseded as a corrosion-resistant alloy until the introduction of stainless steel in this century.

Copper was widely available in the ancient world, but tin was more difficult to come by. A recently excavated Early Bronze Age tin mine in Turkey has revealed details of early production dating from 2870 B.C. that served the Near East's demand for tin to manufacture bronze. This new site, called Kestel, has underground mining shafts that run for more than two miles. The shafts are only about two feet wide, implying that children performed the mining chores. Apparently, the miners lit fires beside veins of tin ore, or cassiterite (the most common oxide ore of tin), to crack the host rock, then dug out the ore with stone implements. It has been suggested that this single mine produced up to 1,000 tons of ore during its period of operation.

The ore was processed into tin metal in the nearby village of Göltepe. The ore was ground up, then heated in covered crucibles until slag that contained tin globules formed. The slag was ground up to free the globules, which were remelted to produce tin ingots. So extensive was this operation that more than 50,000 stone tools have been found at the Göltepe site. Details from this recent discovery provide evidence that tin can be smelted in crucibles at relatively low temperatures. We can thus conclude that the technique may have been more widespread than previously thought.

Ancient tin mines are also found in central Germany, Cantabria in Spain, Brittany in France, and Cornwall in England. Spanish mines had been worked since near the beginning of the Bronze Age, but those in England and France did not begin producing until around 500 B.C. Interestingly, examination of the ancient furnaces in England and Spain has revealed that these early smelters managed to produce tin metal that reached a purity of $99.9 \%$.

The Spanish mines fell into disuse not long after the Cornwall mines began producing. After the Romans' conquest of Britain in 55 B.C., they had access to the Cornwall tin mines. Despite their large output, objects of tin are rarely found among Greek or Roman artifacts because this metal is easily recycled.

Much later, in the 8th and 9th centuries, Arabian writers described the East Indies and the Malay states as new sources of tin. Other mines opened up in Saxony and Bohemia in the 12th century, but the Thirty Years War (1618-1648) destroyed this industry.

Since tin is expensive, it is found chiefly in applications where it can be used sparingly and when other metals will not suffice. Today, about $40 \%$ of all tin produced is used as an electroplated coating on steel food containers-"tin cans." These tin coatings are extremely corrosion resistant in vacuum packs, attractive in appearance, tarnish resistant in air, and completely nontoxic.

\section{KEVIN J. ANDERSON}

FOR Further REAding: "Third Millennium B.C. Tin Processing Debris from Göltepe (Anatolia)" by Pamela Vandiver, K. Aslihan Yener, and Leopold May, in Mater. Res. Soc. Symp. Proc. Vol. 267, 1992, p. 545-569. "Bronze Age Tin Mine Found in Turkey," Science News 145 (1994) p. 46. "Kestel: An Early Bronze Age Source of Tin Ore in the Taurus Mountains, Turkey" by K. Aslihan Yener, Hadi Özbal, Ergun Kaptan, A. Necip Pehlivan, and Martha Goodway, Science 244 (April 14, 1989) p. 200-203. 


\section{Sixth Annual Joint Meeting New Mexico Sections Materials Research Society and American Ceramic Society}

October 31, 1994, Albuquerque, New Mexico

Abstracts (deadline August 15, 1994) are solicited in the following areas:

- Materials Processing and Properties (thin films, membranes, glasses, and composites)

- Materials and Process Characterization (electron microscopy, in situ characterization, sensors)

- Novel and Advanced Materials (biomaterials, electronic materials)

A topical session will be held on Materials Issues in Flat Panel Displays, including an overview of NCAICM (the federal government's National Center for Advanced Information Components Manufacturing program), liquid crystals, field emitters, gas discharge displays and plasma characterization, phosphors, and organic and inorganic electroluminescence.

For information, contact: Kevin Ewsuk, Sandia National Laboratories, Advanced Materials Lab, 1001 University Blvd. SE, Suite 100, Albuquerque, NM 87106. Phone: (505) 272-7620; fax: (505) 272-7304; e-mail: kgewsuk@somnet.sandia.gov.

\section{NEW CVD Gases High Purity Methylsilane}

First reported as a precursor for heteroepitaxial silicon carbide on silicon, methylsilane has more recently been identified as the precursor to a plasma-deposited siliconcarbon-hydrogen polymer which can be used as a dry processable photoresist for high resolution applications. Available in limited quantities with $\geq 99.9 \%$ purity.
Other VOLTAIX Products:

(Applications) Germane, Digermane (a-Si, heteroepi-Si) Diborane, Phosphine (BPSG, a-Si, epi-Si) Silane, Disilane (a-Si, epi-Si) Trimethylboron (BPSG, a-Si)

\section{Deuterated Diborane and Trimethylboron}

Precursors for plasma deposited Tokomak wall passivation and impurity gettering coatings, in the international effort to develop hot fusion energy.

\section{Deuterated Silane}

Offered to improve the performance of silane derived silica for integrated optical waveguides.

01993 VOLTAIX, INC
For more information or to place an order

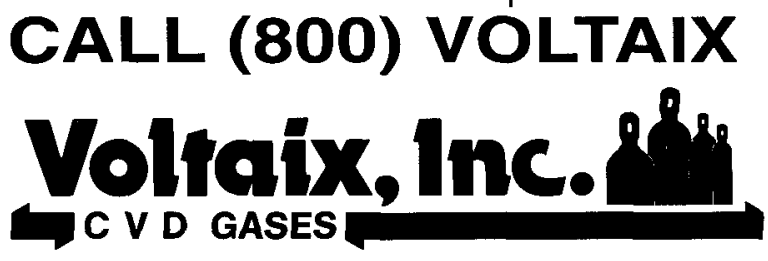

197 Meister Avenue • P.O. Box 5357 - N. Branch, NJ 08876 Fax: (908) 231-9063 - Telephone: (908) 231-9060

This is an"INFOTISEMENT" from Voltaix, Inc.

Your comments or questions are most welcome.

Circle No. 11 on Reader Service Card. 